\title{
Perbedaan respon Aedes aegypti (Linnaeus) (Diptera: Culicidae), terhadap paparan anti nyamuk bakar dan bunga keluwih (Artocarpus camansi, Blanco)
}

\author{
Differential response of Aedes aegypti L., from exposure to \\ mosquitoes coils and breadnut tree flowers \\ (Artocarpus camansi, Blanco) \\ Nur Endah Wahyuningsih ${ }^{1}$, Ramauli Agustina Sihite ${ }^{2}$ \\ ${ }^{1}$ Bagian Kesehatan Lingkungan, Fakultas Kesehatan Masyarakat, Universitas Diponegoro \\ Jalan Prof. Dr. Sudharto SH, Pedalangan Tembalang, Semarang 50239 \\ ${ }^{2}$ Rumah Sakit Umum Daerah Dr. H. Abdul Moeloek \\ Jalan Dr. Rivai No. 6 B, Lampung 35112
}

(diterima Juli 2013, disetujui Oktober 2013)

\begin{abstract}
ABSTRAK
Pengendalian penyakit demam berdarah dengue (DBD) masih bergantung pada pengendalian vektornya, yaitu Aedes aegypti (Linnaeus) dan Ae. albopictus (Skuse). Pengendalian vektor hingga saat ini banyak dilakukan dengan menggunakan insektisida kimia (sintetis). Penelitian tentang status resistensi nyamuk sudah banyak dilakukan, tetapi dampak dari nyamuk yang tetap hidup karena dipajan insektisida sintetis belum banyak diteliti. Tujuan penelitian ini adalah menganalisis perbedaan angka fekunditas, fertilitas dan daya hidup nyamuk yang dipaparkan pada insektisida alami bunga keluwih (Artocarpus camansi) bakar dan insektisida sintetis anti nyamuk bakar berbahan aktif transflutrin dan d allethrin. Telur Ae. aegypti dari lapangan ditetaskan menjadi nyamuk kemudian dipaparkan pada insektisida sintetis dan alami. Setelah ditunggu 24 jam, nyamuk yang hidup dikawinkan. Tiap kelompok tersebut ditempatkan dalam 2 kandang lalu diulang 3 kali. Telur hasil perkawinan diamati sampai nyamuk dewasa mati untuk dibandingkan dengan angka fekunditas, angka fertilitas dan daya hidup. Hasilnya menunjukkan tidak terdapat perbedaan angka fekunditas antara kontrol dan insektisida alami, tetapi ada perbedaan nyata angka fekunditas antara insektisida sintetis dengan kontrol. Insektisida alami tidak meningkatkan angka fekunditas tetapi insektisida sintetis dapat meningkatkan angka fekunditas dan jumlah nyamuk serta menyebabkan umur nyamuk yang lebih panjang dibandingkan dengan perlakuan insektisida alami dan kontrol.
\end{abstract}

Kata kunci: insektisida sintetis, angka fekunditas, fertilitas, daya hidup

\begin{abstract}
The control of dengue hemorrhagic fever (DHF) it is important to control the vector, i.e. Aedes aegypti (Linnaeus) and Ae. albopictus (Skuse). Usually, controls of these vectors are done using chemical insecticides. Research on mosquito resistance has been done, but the impact of mosquitoes that survive after synthetic (chemical) insecticides application has not been studied. The aim of this research was to analyze the differences of fecundity, fertility and vitality rate of mosquitoes that were exposed to natural insecticides i.e with burned breadnut flowers and mosquito coils containing transflutrin and d-aletrin. Mosquito samples were taken from field eggs which were exposed with
\end{abstract}

\footnotetext{
*Penulis korespondensi: Nur Endah Wahyuningsih. Bagian Kesehatan Lingkungan Fakultas Kesehatan Masyarakat, Universitas Diponegoro, Jalan Prof. Dr. Sudharto, SH Tembalang, Semarang

Tel/Faks: +6224 7460044, Email: wahyuningsihnew@gmail.com
} 
synthetic and natural insecticides. Mosquitoes that remainder alive after 24 hours exposure were mated and each group were put in 2 cages, each repetition were repeated 3 times. The mosquito eggs were observed until adult mosquitoes die. Then, the fecundity, fertility and vitality rate were compared. Based on our analysis, there were no differences on fecundity rate, between control and mosquitoes that were exposed to natural insecticides, but there were significant differences between the control and the synthetic insecticides. Natural insecticides do not increase the rate of fecundity but synthetic insecticides may increase the rate of fecundity and number of mosquitoes and causes the mosquito lifespan longer than the control and natural insecticide treatment.

Key words: chemical insecticides, natural insecticides, fecundity, fertility, survival rates

\section{PENDAHULUAN}

Di Indonesia, demam berdarah dengue (DBD) masih menjadi permasalahan serius yang belum terselesaikan. Berdasarkan angka kesakitan (incidence rate/IR) dan angka kematian (case fatality rate $[\mathrm{CFR}])$, tingkat serangan $\mathrm{DBD}$ pada empat dasawarsa terakhir menunjukkan peningkatan dan penurunan. Data Kemenkes RI (2013) menunjukkan terjadi peningkatan IR dari 0,05 per 100.000 penduduk pada tahun 1968 menjadi 65,57 per 100.000 penduduk pada 2010 , sebaliknya, CFR menunjukkan penurunan dari $41,30 \%$ tahun 1968 menjadi $0,87 \%$ pada tahun 2010 . Hal tersebut memperlihatkan adanya permasalahan pada upaya penanggulangan penyakit ini.

Hingga saat ini belum ditemukan vaksin atau obat untuk DBD, sehingga pengendalian penyakit ini bergantung pada pengendalian vektornya, yaitu Aedes aegypti (Linnaeus) dan Ae. albopictus (Skuse). Saat ini pengendalian vektor yang paling banyak dilakukan adalah dengan menggunakan insektisida kimia (sintetis). Umumnya penelitian insektisida bertujuan mengetahui status resistensi organisme target, apakah insektisida tersebut masih potensial dengan konsentrasi yang ditentukan.

Kepekaan nyamuk terhadap insektisida didasarkan atas jumlah kematian nyamuk uji. Mengukuti protokol WHO (1998) nyamuk dinyatakan masih rentan, toleran atau sudah resisten terhadap insektisida jika hasil uji kerentanan berturut-turut menunjukkan kematian sejumlah $98-100 \%, 80-97 \%$ dan kurang dari $80 \%$ nyamuk. Banyak penelitian melaporkan adanya nyamuk yang resisten atau toleran di suatu wilayah. Hal ini berarti di wilayah dengan kondisi toleran atau resisten, sesudah dilaksanakan pemaparan insektisida di wilayah tersebut akan masih terdapat nyamuk yang mampu hidup minimal sebanyak 3-20\% dari total populasi nyamuk. Apa yang terjadi terhadap nyamuk yang tetap hidup setelah mendapat pemaparan? Tulisan ini melaporkan beberapa fakta yang menunjukkan bahwa nyamuk yang tetap hidup setelah pemaparan insektisida sintetis menyebabkan angka fekunditas lebih banyak dan mempunyai lama hidup yang lebih panjang dibandingkan dengan pemaparan insektisida alami dan kontrol.

Dunia mengalami ketergantungan terhadap insektisida karena sejak berakhirnya Perang Dunia II insektisida kimia digunakan secara besar-besaran untuk mengendalikan hama (Shinya 2010; Davies et al. 2007). Sejak itu konsumsinya meningkat di seluruh dunia dan pada tahun 2001, sejumlah 2,26 juta ton bahan aktif digunakan. Dari produksi tersebut $25 \%$ digunakan di negaranegara berkembang tetapi dapat menyebabkan kejadian 99\% kematian akibat pestisida (WHO 2008). Tahun 2004 penggunaan insektisida sekitar 4,4 juta ton setiap tahun dan Amerika Serikat menyumbang lebih dari 25 persen dari pasar ini. Edwards (2004) menyatakan hingga 2004, lebih dari 1.600 pestisida tersedia tetapi Shinya (2010) memprediksi lebih banyak lagi, yaitu terdapat sekitar 5.000 jenis pestisida yang terdaftar dunia.

Beberapa negara di dunia melaporkan adanya nyamuk yang resisten terhadap insektisida, khususnya terhadap dichloro-diphenyl-trichloroethan (DDT), pyrethrins dan pyrethroids (Davies 2007). Selain itu, penelitian di Iran menemukan bahwa nyamuk rumah, Culex quinquefasciatus Say lebih resisten dibandingkan dengan nyamuk laboratorium (Vatandoost et al. 2004). Hasil penelitian tersebut mununjukkan bahwa pada pemaparan dengan insektisida sintetis, nyamuk strain lapangan resisten terhadap DDT, bendiocarb dan toleran terhadap malathion, permethrin, deltamethrin, lambdacyhalothrin dan etofenprox, sedangkan strain nyamuk laboratorium resisten terhadap DDT, tetapi masih rentan terhadap semua 
insektisida yang digunakan (Vatandoost et al. 2004).

Di Indonesia nyamuk habitat luar rumah (Ae. albopictus) maupun dalam rumah (Culex quinquefasciatus) berpotensi lebih toleran terhadap insektisida, karena seringnya kontak dengan insektisida malathion saat dilakukan pengasapan (fogging) masal (Gionar et al. 2005). Di Yogyakarta dilaporkan bahwa dengan uji biokimia dan uji hayati (bioassay), larva Ae. aegypti cenderung resisten terhadap malathion dan temefos (Gionar et al. 2005). Gejala toleran terhadap insektisida organofospat juga ditunjukkan oleh populasi Ae. albopictus di Jakarta dan Bali, dengan strain Jakarta lebih banyak yang toleran daripada strain Bali.

Data yang ada menunjukkan bahwa nyamuk lapangan lebih resisten dibandingkan dengan nyamuk laboratorium sedangkan nyamuk Jakarta lebih resisten daripada nyamuk Bali. Hal ini diduga karena nyamuk lapangan lebih sering terpapar insektisida yang digunakan oleh masyarakat dibandingkan dengan nyamuk laboratorium. Untuk membuktikan pengaruh resistensi nyamuk, ingin diketahui pengaruh insektisida sintestis dibandingkan dengan insektisida alami terhadap angka fekunditas, fertilitas dan daya hidup nyamuk. Tujuan penelitian adalah menganalisis resistensi populasi nyamuk terhadap dua jenis insektisida, yaitu insektisida alami bunga keluwih (Artocarpus camasi) dan insektisida sintetis anti nyamuk bakar berbahan aktif transflutrin dan $\mathrm{d}$ allethrin.

\section{BAHAN DAN METODE}

Persiapan penelitian dimulai dengan memasang ovitrap untuk mendapatkan telur lapangan. Telur kemudian dipelihara hingga menjadi nyamuk (dinyatakan sebagai nyamuk parental). Nyamuk parental ini kemudian dipaparkan pada insektisida konsentrasi sublethal $\left(\mathrm{LC}_{50}\right)$, yang menyebabkan $50 \%$ nyamuk hidup. Nyamuk yang tetap hidup setelah dipapar insektisida dan didiamkan selama 24 jam, digunakan untuk penelitian. Selain itu, digunakan juga nyamuk kontrol, yaitu nyamuk yang tidak mendapat paparan insektisida alami dan buatan, digunakan ketika nyamuk perlakuan selesai dipapar. Banyaknya nyamuk kontrol adalah 50\% dari jumlah nyamuk sebelum dipapar. Nyamuknyamuk ini kemudian dikawinkan lalu telur yang dihasilkan diikuti perkembangannya sampai menjadi dewasa dan mati. Untuk pertumbuhannya nyamuk Ae. aegypti diberi cairan gula dan darah marmut setiap hari pada suhu antara $27,4-28,8^{\circ} \mathrm{C}$ dan kelembapan antara $75,5-83,3 \%\left(25 \pm 3{ }^{\circ} \mathrm{C}\right.$ dan $75 \pm 10 \%)$.

\section{Pemasangan ovitrap telur lapangan}

Ovitrap digunakan sejak pertama kali dilakukan pengumpulan telur Ae. aegypti dari lapangan. Jumlah telur yang dikumpulkan, disiapkan untuk memenuhi kebutuhan 450 individu nyamuk. Pengumpulan dilakukan mulai 4 April 2010 sampai 26 Juni 2010, selama 84 hari. Waktu pengumpulan nyamuk tersebut cukup lama, karena penelitian ini dilakukan pada musim kemarau sehingga sulit mendapatkan telur. Ovitrap berupa botol plastik yang dipotong di bagian mulutnya dan dicat warna hitam, didalamnya diletakkan kertas saring berbentuk empat persegi panjang sebagai media nyamuk bertelur.

Lokasi pemasangan ovitrap adalah di Kelurahan Jabungan, Kecamatan Banyumanik, Kota Semarang. Selama pemasangan ovitrap, dilakukan monitoring meliputi kegiatan pengecekan keberadaan ovitrap, pengecekan telur, pengecekan air dan kertas saring dalam ovitrap, serta penggantian kertas saring dengan yang baru. Monitoring disamakan setiap 2 hari sekali.

\section{Pemeliharaan terhadap telur yang dikoleksi dari lapangan}

Telur yang terkumpul dikeringkan dan dimasukkan ke dalam wadah plastik bertutup dan diberi silica gel agar terhindar dari hewan pemangsa telur nyamuk (misal semut), kemudian secepatnya ditetaskan. Penetasan telur nyamuk dilakukan dalam nampan berisi air sampai telur menjadi larva/jentik. Air yang digunakan adalah air sumur artetis di Laboratorium Parasitologi, Fakultas Kedokteran, Universitas Diponogoro. Larva berubah menjadi pupa dalam waktu \pm 7 hari dan setiap hari larva diberi makan keju. Pupa selanjutnya diambil dan dipisahkan satu persatu menggunakan pipet dan dimasukkan ke dalam gelas plastik kecil berisi air sumur artetis yang pada bagian atasnya ditutup dengan kain kasa 
lalu diikat menggunakan karet dan ditempatkan pada nampan yang tersedia. Hal ini dimaksudkan untuk memudahkan identifikasi ketika pupa sudah berubah menjadi nyamuk. Setelah 1-3 hari pupa berubah menjadi nyamuk. Nyamuk parental dari telur lapangan ini diidentifikasi spesies untuk mendapatkan nyamuk Ae. aegypti jantan dan betina.

\section{Perlakuan pemaparan nyamuk terhadap dua jenis insektisida}

Pemaparan $\mathrm{LC}_{50}$ terhadap insektisida alami dan insektisida sintetis dilakukan terhadap nyamuk jantan dan betina secara terpisah. Insektisida alami adalah bunga keluwih jantan (Artocarpus camasi), yaitu bunga jantan dari tanaman keluwih yang menyerupai busa, panjang $\pm 25 \mathrm{~cm}$, berwarna kuning kecoklatan, mirip ekor kucing yang terkulai. Insektisida sintetis adalah anti nyamuk bakar berbahan aktif transfluthrin dan d allethrin memiliki bahan aktif transfluthrin 0,03\%. Besarnya kadar bunga keluwih jantan maupun anti nyamuk bakar dalam menghasilkan $\mathrm{LC}_{50}$ didapatkan melalui penelitian pendahuluan, dengan cara menerapkan beberapa kadar sehingga didapatkan jumlah kematian nyamuk yang diharapkan (WHO 2009). Hasilnya untuk mendapatkan $\mathrm{LC}_{50}$ diperlukan bunga keluwih jantan sebanyak 2,4 $\mathrm{g}$ sedang anti nyamuk bakar berbahan aktif transfluthrin dan $\mathrm{d}$ allethrin sebanyak $0,4 \mathrm{~g}$.

Pemaparan dilakukan di dalam glass chamber, yaitu suatu kotak kaca berukuran $70 \mathrm{~cm}$ x $70 \mathrm{~cm}$ x $70 \mathrm{~cm}$ dengan satu dindingnya dapat dibuka berupa jendela geser ukuran $20 \mathrm{~cm}$ x $20 \mathrm{~cm}$. Pemaparan dilakukan menggunakan 2 glass chamber, masing-masing untuk memajan nyamuk jantan dan nyamuk betina, dengan waktu pajanan 20 menit, sesuai prosedur laboratorium untuk uji efikasi insektisida (B2P2VRP 2011).

Pertama-tama pemajanan dilakukan terhadap nyamuk perlakuan bunga keluwih, setelah seluruh proses pemajanan perlakuan bunga keluwih selesai, glass chamber dicuci sampai bersih dan ditunggu beberapa saat untuk kemudian digunakan lagi untuk memajan nyamuk perlakuan berikutnya, yaitu insektisida sintetis.

Sebelum pengujian, kedua glass chamber perlu dipastikan dalam keadaan bersih, tidak terkontaminasi. Indikator kebersihan menggunakan rumus Abbot, kematian yang dapat ditolerir sebesar $\leq 20 \%$ (WHO 2009). Pemajanan meng- gunakan bunga keluwih jantan, dimulai dengan menimbangnya sebanyak 2,4 g, kemudian dipasang pada penjepit kawat dan diletakkan di atas cawan kaca. Kedua ujung bunga keluwih dibakar secara bersamaan dan dimasukkan ke dalam glass chamber. Pemajanan memakai anti nyamuk bakar berbahan aktif transfluthrin dan d allethrin, diawali dengan menimbang anti nyamuk bakar sebanyak $0,4 \mathrm{~g}$, kemudian dipasang pada penjepit kawat dan diletakkan di atas cawan. Kedua ujung anti nyamuk, dibakar secara bersamaan dan dimasukan ke dalam glass chamber.

Ketika dilakukan pembakaran bahan pemajan, di dalam glass chamber dipasang kipas kecil kemudian dihidupkan untuk menghindari hembusan langsung bahan pemajan (bunga keluwih atau anti nyamuk bakar). Waktu untuk membakar bahan pemajanan sampai habis (burning time) dicatat. Setelah bahan pemajan habis terbakar, kipas angin dan cawan kaca dikeluarkan. Sebanyak 25 nyamuk jantan dimasukkan ke dalam glass chamber I dan 25 nyamuk betina ke dalam glass chamber II. Setiap perlakuan (2 perlakuan) masing-masing dilakukan 3 kali ulangan.

Selama periode pemaparan 20 menit, jumlah nyamuk pingsan atau mati dicatat. Setelah dipajan, semua nyamuk yang sudah dipajan dipindahkan ke dalam gelas plastik yang diberi kapas dan dibasahi dengan $10 \%$ sukrosa. Nyamuk dibiarkan selama 24 jam, masih dalam keadaan terpisah antara jantan dan betina, setiap gelas plastik berisi maksimum 15 individu nyamuk dan diberi label betina atau jantan. Setelah disimpan selama 24 jam jumlah nyamuk yang mati dihitung sedangkan nyamuk yang tetap hidup dipelihara untuk perlakuan berikutnya (Tabel 1).

\section{Perlakuan terhadap nyamuk yang berhasil bertahan hidup}

Nyamuk dari telur lapangan (nyamuk parental) yang tetap hidup setelah pemaparan 20 menit dan disimpan selama 24 jam, kemudian dikopulasikan. Dalam hal ini, selain nyamuk perlakuan nyamuk kontrol juga diambil. Nyamuk-nyamuk ini dimasukkan ke dalam kandang berisi paper cup. Paper cup berfungsi sebagai ovitrap, didalamnya terdapat kertas saring berbentuk empat persegi panjang dan air. Masing-masing kelompok (2 perlakuan dan 1 kontrol) dikawinkan. Tiap kelompok ditempatkan dalam 2 kandang lalu diulang 3 kali. 
Tabel 1. Nyamuk mati dan sisa nyamuk hidup setelah pemajanan LC 50

\begin{tabular}{|c|c|c|c|c|c|c|c|c|c|c|}
\hline & \multirow{3}{*}{ Ulangan } & \multirow{3}{*}{ Kontrol } & \multicolumn{8}{|c|}{ Perlakuan* } \\
\hline & & & \multicolumn{4}{|c|}{ Bunga keluwih } & \multicolumn{4}{|c|}{ Transfluthrin } \\
\hline & & & \multicolumn{2}{|c|}{ Mati } & \multicolumn{2}{|c|}{ Hidup } & \multicolumn{2}{|c|}{ Mati } & \multicolumn{2}{|c|}{ Hidup } \\
\hline \multirow{4}{*}{ Betina } & 1 & 12 & $\mathrm{n}$ & $\%$ & $\mathrm{n}$ & $\%$ & $\mathrm{n}$ & $\%$ & $\mathrm{n}$ & $\%$ \\
\hline & $\frac{1}{2}$ & $\begin{array}{l}12 \\
12\end{array}$ & 11 & 44 & 14 & 56 & 11 & 44 & 14 & 56 \\
\hline & $\begin{array}{l}2 \\
3\end{array}$ & $\begin{array}{l}12 \\
12\end{array}$ & 11 & 44 & 14 & 56 & 12 & 48 & 13 & 52 \\
\hline & & & 12 & 48 & 13 & 52 & 12 & 48 & 13 & 52 \\
\hline Total & & & 34 & & 41 & & 35 & & 40 & \\
\hline \multirow[t]{3}{*}{ Jantan } & $\begin{array}{l}1 \\
2\end{array}$ & $\begin{array}{l}12 \\
12\end{array}$ & 10 & 40 & 15 & 60 & 10 & 40 & 15 & 60 \\
\hline & 2 & $\begin{array}{l}12 \\
12\end{array}$ & 10 & 40 & 15 & 60 & 12 & 48 & 13 & 52 \\
\hline & 3 & 12 & 10 & 40 & 15 & 60 & 10 & 40 & 15 & 60 \\
\hline Total & & & 30 & & 45 & & 32 & & 43 & \\
\hline
\end{tabular}

*Setiap perlakuan (2 perlakuan dan 1 kontrol) dilakukan pada 2 glass chamber masing masing untuk nyamuk jantan dan nyamuk betina. Setiap glass chamber dilakukan $3 \mathrm{x}$ ulangan.

Setiap kandang berisi 5 pasang nyamuk dewasa. Setiap kandang diberi makan air madu (sukrosa) $10 \%$ serta disiapkan marmut usia $2-3$ bulan untuk makan darah nyamuk. Marmut dikurung di dalam kandang kecil dan dicukur sebagian rambut punggungnya untuk memudahkan nyamuk dalam menghisap darah.

\section{Pengumpulan data}

Data yang diperoleh berupa jumlah telur, persentase telur menetas dan daya hidup (larva survive, pupa survive dan nyamuk dewasa survive) kemudian dihitung angka fekunditas, angka fertilitas dan daya hidupnya.

\section{Jumlah telur (F1)}

Perhitungan terhadap jumlah telur dilakukan setelah 3 hari nyamuk dikawinkan dan telah melewati satu siklus genotropik. Penghitungan telur dilakukan setiap hari sampai nyamuk tidak mengeluarkan telur lagi, yaitu selama kurang lebih 6 hari pengamatan dimulai setelah nyamuk diberi makan darah. Penghitungan dilakukan mulai pukul 08:00 WIB

\section{Jumlah telur menetas}

Telur yang telah dihitung langsung ditetaskan dalam tempayan berisi air sumur. Lama penetasan ditunggu sampai 5 hari. Hal ini karena, siklus gonotrofik nyamuk Ae. aegypti tergantung pada suhu. Pada suhu $28^{\circ} \mathrm{C}$ satu siklus adalah 3,5 hari, sedangkan pada suhu $30^{\circ} \mathrm{C}$ lebih pendek, yaitu 2,9 hari (Focks \& Barrera 2007). Dalam penelitian ini tidak dilakukan penelitian ulang siklus gonotropik, tetapi mengikuti Focks \& Barrera (2007), kurang lebih 3 hari karena suhu berkisar antara $28-32{ }^{\circ} \mathrm{C}$ kemudian penghitungan telur menetas ditambah 2 hari lagi untuk memberi kesempatan telur yang lambat menetas. Telur yang menetas menjadi larva sebelum 6 hari dianggap sebagai telur yang menetas dan telur yang belum menetas menjadi larva setelah 6 hari dianggap sebagai telur yang tidak menetas. Penghitungan telur menetas dilakukan menggunakan alat hitung (counter).

\section{Angka fekunditas, fertilitas dan daya hidup}

Angka fekunditas adalah jumlah telur yang dihasilkan oleh sepasang nyamuk dalam satu kali masa peneluran (butir). Angka fertilitas adalah jumlah telur yang mampu menetas. Fertilitas diekspresikan dalam persentase. Daya hidup dihitung dari hasil perkawinan nyamuk parental (P). Perhitungan daya hidup nyamuk filial 1 (F1) terdiri atas (a) Persentase larva yang survive (\%), yaitu banyaknya larva yang menjadi pupa dibagi jumlah larva seluruhnya dikalikan 100\%. Larva yang berubah menjadi pupa setelah 5 hari dianggap sebagai larva yang tidak berhasil berubah menjadi pupa; (b) Lamanya larva yang hidup (hari), yaitu lamanya larva bertahan hidup sampai menjadi pupa (ditentukan 5 hari); (c) Persentase pupa yang survive (\%), yaitu banyaknya pupa yang bertahan hidup sampai menjadi nyamuk dibagi dengan jumlah seluruh pupa dikalikan $100 \%$. Pupa yang berubah menjadi nyamuk setelah 5 hari dianggap sebagai pupa yang tidak berhasil berubah menjadi 
nyamuk; (d) Lamanya pupa hidup (hari), adalah lamanya pupa bertahan hidup sampai menjadi nyamuk (ditentukan 5 hari); (e) Banyaknya nyamuk survive dihitung berdasarkan banyaknya nyamuk mati per hari (f) Lamanya nyamuk yang hidup (hari) dihitung dari saat lamanya nyamuk hidup sampai nyamuk tersebut mati.

\section{Analisis data}

Data angka fekunditas, fertilitas dan daya hidup nyamuk diuji normalitas dengan Shapiro Wilk, homogenitas dengan levene test dan diuji beda dengan Anova One-way. Data yang normal dan homogen diuji lanjut dengan Post Hoc Tukey sedangkan data yang tidak normal diuji menggunakan Kruskal Wallis dan Mann Whitney U. Semua data dianalisis menggunakan perangkat lunak SPSS ver 17.

\section{HASIL}

\section{Angka fekunditas, fertilitas dan daya hidup}

Hasil penelitian menunjukkan bahwa nyamuk dengan fekunditas tertinggi didapatkan pada perlakuan anti nyamuk bakar. Fertilitas, daya hidup larva dan daya hidup pupa tidak berbeda nyata antar perlakuan dan kontrol. Nyamuk mati paling banyak terdapat pada kontrol. Jumlah telur Ae. aegypti pada kontrol dan pemajanan bunga keluwih dan anti nyamuk bakar berturut-turut sebesar 1.336, 1.411 dan 1.696 butir. Hasil ini memperlihatkan bahwa jumlah telur paling banyak didapat dari pemajanan insektisida sintetis. Hasil uji beda angka fekunditas Ae. aegypti antara kontrol, pemajanan bunga keluwih dan anti nyamuk bakar berbeda nyata $\left(\mathrm{F}_{2,89}=12,009 ; \mathrm{P}=0,000\right)$. Hasil uji lanjutan (Post Hoc, Tukey), didapatkan angka fekunditas nyamuk Ae. aegypti antara kontrol dengan pemajanan bunga keluwih $(44,5 \pm 10,3$ dan $47 \pm 10,1$ butir) tidak berbeda, tetapi angka fekunditas antara pemajanan anti nyamuk bakar dengan kontrol $(44,5 \pm 10,3$ dan 56,5 \pm 9,7 butir) dan memperlihatkan perbedaan nyata (Tabel 2).

Jumlah telur Ae. aegypti yang mampu menetas pada kontrol, pemajanan bunga keluwih dan anti nyamuk bakar berturut-turut sebesar 858, 917 dan 1.122 butir. Rerata dan SD telur menetas per pasang Ae. aegypti pada kontrol, pemajanan bunga keluwih dan anti nyamuk bakar berturut-turut sebesar 28,6 \pm 8,2, 30,6 \pm 8,3 dan 37,4 \pm 6,9 butir. Rerata dan SD angka fertilitas Ae. aegypti yang paling besar adalah pemajanan dari anti nyamuk bakar, yaitu sebesar $66,4 \pm 7.1 \%$ dibandingkan dengan kontrol dan pemajanan bunga keluwih $64,1 \pm 9.2 \%$ dan $64,6 \pm 8.0 \%$ (Tabel 2). Hasil ini memperlihatkan bahwa jumlah telur menetas paling banyak, rerata telur menetas terbanyak dan rerata fertilitas paling banyak juga didapat dari perlakuan insektisida sintetis.

Meskipun rerata angka fertilitas anti nyamuk bakar adalah yang paling besar diantara perlakuan, tetapi tidak memperlihatkan ada perbedaan nyata. Hasil uji beda angka fertilitas ketiganya $\left(\mathrm{F}_{2,89}=\right.$ 0,$631 ; \mathrm{P}=0,534$ ) (Tabel 2). Dengan angka fekunditas yang lebih besar dan angka fertilitas yang sama, maka diantara ketiga perlakuan jumlah jentik yang paling banyak adalah hasil pajanan insektisida sintetis.

\section{Daya hidup larva dan pupa}

Daya hidup larva dan pupa Ae. aegypti kontrol, pemajanan bunga keluwih dan anti nyamuk bakar memperlihatkan rerata dan SD yang hampir sama dan tidak terdapat perbedaan hasil uji beda daya hidup larva dan pupa Ae. aegypti antara kontrol, pemajanan bunga keluwih dan anti nyamuk bakar $\left(\mathrm{F}_{2,17}=2,172 ; \mathrm{P}=0,148\right)$ dan $\left(\mathrm{F}_{2,17}=1,000 ; \mathrm{P}=\right.$ 0,391 ) (Tabel 3).

Tabel 2. Hasil uji beda angka fekunditas dan fertilitas Aedes aegypti pada pemajanan bunga keluwih, anti nyamuk bakar dan kontrol di Laboratorium Parasitologi Fakultas Kedokteran UNDIP, Tahun 2010

\begin{tabular}{lc}
\hline Pemajanan & Rerata* $^{*}$ \\
\hline Angka fekunditas (butir) & $44,5 \pm 10,3 \mathrm{a}$ \\
$\quad$ Kontrol & $47,0 \pm 10,1 \mathrm{a}$ \\
Bunga keluwih & $56,5 \pm 9,7 \mathrm{~b}$ \\
Anti nyamuk bakar & \\
Angka fertilitas (\%) & $64,1 \pm 9,2 \mathrm{a}$ \\
Kontrol & $64,6 \pm 8,0 \mathrm{a}$ \\
Bunga keluwih & $66,4 \pm 7,1 \mathrm{a}$ \\
Anti nyamuk bakar &
\end{tabular}

*Angka pada kolom yang sama yang diikuti oleh huruf yang sama menyatakan tidak beda nyata dengan uji Post Hoc, Tukey taraf $5 \%$. 


\section{Daya hidup nyamuk (Banyaknya nyamuk mati per hari dan lama hidup nyamuk)}

Daya hidup nyamuk dihitung berdasarkan jumlah nyamuk yang mati per hari dan lama hidup nyamuk sampai seluruh sampel nyamuk mati. Gambar 1 merupakan total jumlah nyamuk yang dihasilkan serta lama hidup nyamuk dari setiap kelompok perlakuan, didapat dengan mencatat jumlah nyamuk yang mati sejak hari pertama dihasilkan atau dinyatakan sebagai banyaknya nyamuk yang mampu survive. Banyaknya nyamuk survive dari kelompok kontrol, pemajanan bunga keluwih dan pemajanan insektisida sintetis berturut turut sebanyak 485, 532 dan 624 individu (Gambar 1).

Sedangkan jika dihitung berdasarkan jumlah nyamuk yang mati per hari memperlihatkan bahwa jumlah nyamuk mati setiap hari yang paling sedikit berasal dari kelompok pemajanan anti nyamuk bakar, yaitu sebesar 19 individu, dan terbanyak dari kelompok kontrol sebesar 29 inividu. Hasil uji beda banyaknya nyamuk mati antara kontrol dengan pemajanan bunga keluwih dan anti nyamuk bakar memperlihatkan perbedaan nyata $\chi_{2}=$ 6,018; P = 0,049 (Kruskall Wallis) (Tabel 3). Hasil uji lanjut (Mann Whitney U) antara kontrol dengan pemajanan bunga keluwih memperlihatkan tidak berbeda nyata dengan $\mathrm{P}=0,056$. Tetapi terdapat perbedaan nyata hasil uji beda antara kontrol dengan anti nyamuk bakar dengan $\mathrm{P}=0,019$. Uji beda daya hidup nyamuk (Ae. aegypti mati) antara pemajanan bunga keluwih dan anti nyamuk bakar tidak berbeda nyata dengan $\mathrm{P}=0,574$.
Median lama hidup nyamuk antara kelompok kontrol, pajanan bunga keluwih dan insektisida sintetis memperlihatkan lama hidup terpanjang didapat pada perlakuan pemajanan insektisida sintetis, yaitu selama 35 hari. Hasil uji beda lama hidup Ae. aegypti antara kontrol, pemajanan bunga keluwih dan anti nyamuk bakar berbeda nyata $\chi_{2}=15,692 ; \mathrm{P}=0,000$ (Kruskal Wallis).

Tabel 3. Hasil uji beda daya hidup Aedes Aegypti pada pemajanan bunga keluwih, anti nyamuk bakar dan kontrol di Laboratorium Parasitologi Fakultas Kedokteran Universitas Diponogoro tahun 2010

\begin{tabular}{ll}
\hline Pemajanan & Rerata* $^{*}$ \\
\hline Larva survive (\%) & $74,7 \pm 2,7 \mathrm{a}$ \\
Kontrol & $79,6 \pm 5,5 \mathrm{a}$ \\
Bunga keluwih & $74,9 \pm 5,1 \mathrm{a}$ \\
Anti nyamuk bakar & \\
Pupa survive (\%) & $75,8 \pm 3,3 \mathrm{a}$ \\
Kontrol & $73,3 \pm 3,4 \mathrm{a}$ \\
Bunga keluwih & $74,4 \pm 2,5 \mathrm{a}$ \\
Anti nyamuk bakar & Median \\
Banyaknya nyamuk mati per & \\
hari (individu) & $29 \mathrm{a}$ \\
Kontrol & $22 \mathrm{ab}$ \\
Bunga keluwih & $19 \mathrm{~b}$ \\
Anti nyamuk bakar & \\
Lama hidup nyamuk (hari) & $22 \mathrm{a}$ \\
Kontrol & $29 \mathrm{~b}$ \\
Bunga keluwih & $35 \mathrm{c}$ \\
Anti nyamuk bakar &
\end{tabular}

*Angka pada kolom yang sama yang diikuti oleh huruf yang sama menyatakan tidak beda nyata dengan uji Mann Whitney U pada taraf 5\%.

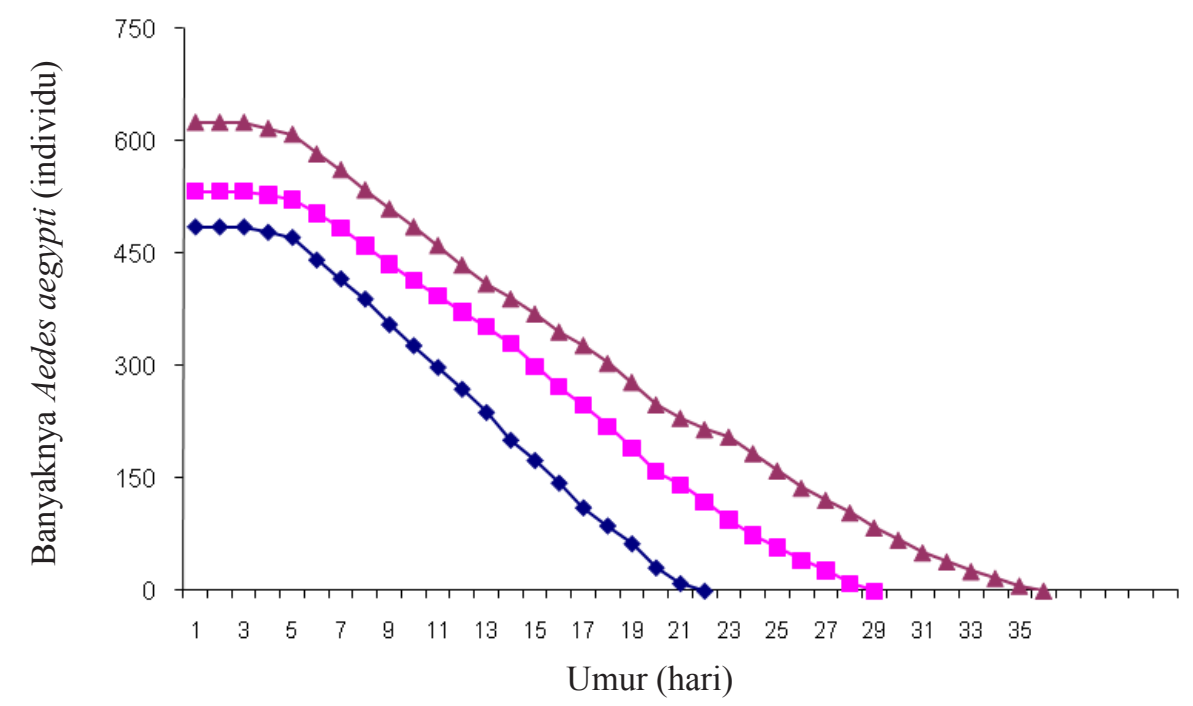

Gambar 1. Perbandingan jumlah individu dan umur nyamuk Aedes aegypti kontrol, pajanan bunga keluwih dan anti nyamuk bakar. Kontrol $(\rightarrow)$; bunga keluwih $(-)$; dan anti nyamuk bakar $(\rightarrow)$. 
Hasil uji lanjutan (Mann Whitney U), didapatkan lama hidup nyamuk Ae. aegypti antara kontrol, pemajanan bunga keluwih dan anti nyamuk bakar terdapat perbedaan nyata berturut turut dengan $\mathrm{P}=0,001,0,002$ dan 0,002 (Tabel 3).

\section{PEMBAHASAN}

Hasil penelitian menunjukkan bahwa angka fekunditas terbanyak didapat dari perlakuan pemajanan insektisida sintetis. Angka fekunditas hasil pajanan $\mathrm{LC}_{50}$ insektisida sintetis menyebabkan perbedaan nyata baik dengan kontrol maupun bunga keluwih. Hasil ini memperlihatkan kuatnya pajanan insektisida dalam meningkatkan kemampuan bertelur Ae. aegypti. Hasil ini berbeda dengan hasil Vasuki (1999), yang meneliti paparan insect growth regulator (IGR/regulator pertumbuhan serangga) hexafumuron, terhadap tahap larva dan pupa, hasilnya jumlah telur nyamuk Ae. aegypti menurun menjadi $30-45 \%$.

Hasil pemajanan bunga keluwih $\mathrm{LC}_{50}$ menunjukkan bahwa angka fekunditas sedikit berbeda dengan kontrol dan secara statistik tidak berbeda nyata. Hasil ini memperlihatkan bahwa pajanan bunga keluwih jantan tidak merubah kemampuan nyamuk dalam bertelur. Hasil ini hampir sama dengan penelitian Antonio et al. (2009), yang memapar larva Ae. aegypti dari Chiapas Mexico Selatan dengan $\mathrm{LC}_{50}$ Spinosad (senyawa macrolide tetrasiklik alami yang didapatkan dari fermentasi aktinomisetes tanah) selama 1 jam paparan, menyebabkan telur F1 lebih banyak dibandingkan dengan kontrol. Antonio (2009) melakukan pemaparan pada fase larva sedangkan pada penelitian ini pemaparan dilakukan pada fase dewasa.

Angka fertilitas tertinggi penelitian ini juga didapatkan dari nyamuk perlakuan pemajanan insektisida sintetis, meskipun tidak terdapat perbedaan nyata angka fertilitas antara kontrol, pajanan insektisida alami dan insektisida sintetis.

Daya hidup memperlihatkan kemampuan organisme dalam bertahan hidup. Semakin lama suatu organisme hidup berarti organisme tersebut semakin kuat. Nyamuk Ae. aegypti yang diberi cairan gula dan darah marmut setiap hari pada suhu $25 \pm 3{ }^{\circ} \mathrm{C}$ dan kelembapan $75 \pm$ $10 \%$, memperlihatkan perbandingan daya hidup nyamuk yang berbeda oleh berbedanya perlakuan antara kelompok kontrol, pajanan bunga keluwih dan insektisida sintetis. Hasilnya jumlah nyamuk lebih banyak dan umur nyamuk lebih panjang. Hasil ini konsisten dengan nyamuk mati per hari, yaitu paling tinggi pada kontrol dan paling rendah pada pajanan insektisida sintetis. Ada perbedaan umur nyamuk survive antara kontrol dengan perlakuan insektisida alami maupun sintetis. Nyamuk yang dipajan anti nyamuk bakar memiliki lama hidup paling panjang, yaitu 35 hari. Hal ini memperlihatkan pajanan insektisida sintetis dapat memperpanjang lama hidup nyamuk.

Hasil uji menunjukkan bahwa jumlah nyamuk Ae. aegypti yang mati antara perlakuan pemaparan bunga keluwih dan kontrol tidak berbeda nyata, demikian juga dengan hasil uji antar perlakuan pemaparan bunga keluwih dan anti nyamuk bakar yang tidak berbeda nyata. Akantetapi, terdapat perbedaan nyata daya hidup nyamuk yang mati (Ae. aegypti mati) antara kontrol dan anti nyamuk bakar, $P=0,019$. Dengan kata lain pajanan bahan kimia alami lebih ditolerir oleh nyamuk dibandingkan dengan pajanan bahan kimia sintetis. Agak berbeda dengan hasil Antonio et al. (2009) yang meneliti lama hidup nyamuk setelah larva dipapar dengan bahan alami spinosad, mendapati bahwa bahan alami tersebut tidak menyebabkan perbedaan nyata lama hidup nyamuk antara kontrol dan perlakuan. Hasil Antonio (2009) mendukung pendapat bahwa bahan kimia alami lebih ditolerir dan tidak merubah nyamuk

Secara keseluruhan kapasitas nyamuk $A e$. aegypti meningkat oleh pajanan insektisida sintetis berbahan aktif transflutrin dan d-allethrin. Hal ini diperlihatkan dengan paling banyaknya angka fekunditas, banyaknya dan lamanya nyamuk bertahan hidup dibandingkan dengan kontrol atau pemaparan bunga keluwih.

Wahyuningsih et al. (2009) pada tahun 2008 meneliti nyamuk kontrol (tanpa pemajanan, dari telur lapangan), dan mendapatkan bahwa lama hidup nyamuk 17 hari. Penelitian ini (tahun 2010) dilakukan di tempat sama pada interval suhu dan kelembaban sama, yaitu antara $27,5-30,5{ }^{\circ} \mathrm{C}$ dan $72,4-79,3 \%\left(25 \pm 3{ }^{\circ} \mathrm{C}\right.$ dan $\left.75 \pm 5 \%\right)$, dengan selisih waktu dua tahun (tahun 2010). Lama hidup nyamuk kontrol penelitian ini 22 hari. Hal ini memperlihatkan lama hidup nyamuk tahun 2010 
lebih panjang 4 hari. Terdapat selisih lama hidup nyamuk pada pengambilan sampel selang dua tahun.

Hasil ini mendukung dugaan bahwa nyamuk yang resisten/tetap hidup setelah dipajan insektisida sintetis, mengembangkan kemampuan adaptasi menjadi lebih kuat. Dugaan sementara, organisme tingkat rendah (misalnya nyamuk) yang mendapat paparan bahan kimia sintetis (seperti insektisida sintetis) akan lebih cepat mengembangkan kemampuan adaptasi dan menjadi lebih kuat dibandingkan dengan sebelumnya. Semakin banyak insektisida yang digunakan, semakin toleran nyamuk terhadap insektisida dan semakin kuat.

Sumber insektisida yang digunakan di lapangan, dapat berasal dari rumah tangga ataupun program. Penggunaan insektisida di rumah tangga terkait dengan perilaku masyarakat dalam mengusir nyamuk. Penggunaan insektisida oleh program terkait dengan kebijakan di pertanian dan program pengendalian vektor. Dalam hal ini, adanya selisih lama hidup nyamuk 4 hari pada selama kurun waktu 2 tahun, kemungkinan disebabkan oleh berubahnya resistensi nyamuk lapangan. Untuk membuktikannya, perlu diteliti apakah intensitas penggunaan insektisida sintetis di masyarakat, selama kurun waktu 2 tahun tersebut, meningkat.

Indikator nyamuk yang lebih kuat diketahui dari daya hidupnya, diantaranya dari lama hidup nyamuk yang semakin panjang. Berubahnya lama hidup nyamuk ini kemungkinan dapat disebabkan oleh adanya mutasi gen di dalam tubuh nyamuk. Hasil penelitian Srisawat et al. (2012) mendeteksi ada mutasi gen pada nyamuk resisten Permetrin. Hasil sekuen gen knock down resistant (KDR) memperlihatkanterdapatmutasititik duanukleotida yang menyebabkan dua substitusi asam amino yang terletak pada gen KDR domain II S6 dari membran sel syaraf nyamuk, pada protein saluran natrium. Fungsi yang sebenarnya dari saluran ini adalah transmisi normal dari impuls syaraf dan proses ini diganggu oleh adanya pengikatan insektisida yang menyebabkan kelumpuhan/ paralysis dan akhirnya kematian. Mutasi titik dua nukleotida tersebut adalah perubahan Ser989Pro dan Val1016Gly, yaitu berturut turut terjadi perubahan pembentukan asam amino dari Serine (TCC) menjadi Proline (CCC) dan dari asam amino Valine (GTA) menjadi Glysine (GGA), kedua mutasi ini dinyatakan selalu muncul pada nyamuk resisten permetrin.

Davies et al. 2007, mengidentifikasi substitusi asam amino pada serangga resisten mengurangi sensitivitas terhadap pyrethroid dan atau DDT, menyebabkan nyamuk tidak mati oleh pemaparan insektisida. Substitusi kebanyakan terjadi pada Domain II S4-S6 dan dilaporkan menyebabkan terjadi 14 perubahan pada 30 spesies serangga dan 11 perubahan pada 6 spesies serangga. Selain domain II, mutasi yang terjadi di luar domain II menyebabkan 22 perubahan pada 7 spesies serangga. Lebih lanjut Davies et al. (2008) menemukan bahwa yang mendasari resistensi insektisida selain gen KDR juga gen SUPER-KDR. Gen KDR menurunkan sensitivitas sebesar 10-20 kali terhadap lokasi sasaran, sedangkan gen SUPER KDR mengurangi sensitivitas 10 kali lebih banyak dibandingkan dengan gen KDR atau 100 kali penurunan dibandingkan dengan yang tidak resisten. Hal tersebut dapat menjelaskan mengapa nyamuk dengan pajanan insektisida tidak saja tidak mati oleh pemaparan insektisida tetapi justru memiliki lama hidup lebih panjang dibandingkan dengan kontrol dan yang dipapar insektisida alami.

Dampak lanjut bertambah panjangnya lama hidup nyamuk dapat berpengaruh pada kemampuan gonotrofik. Jika satu siklus gonotrofik perlu waktu 3 hari dan secara teori jumlah telur normal yang dihasilkan antara 10-100 butir pada setiap siklus gonotropik, maka lama hidupyang lebih panjang akan menambah siklus gonotropik dan terkait dengan kemampuan berkembang biak nyamuk. Banyaknya siklus gonotropik nyamuk laboratorium hasil penelitian De Freitas et al. (2007) di Brazil, memperlihatkan siklus gonotropik nyamuk laboratorium pada suhu dan kelembapan hampir sama $\left(25 \pm 3{ }^{\circ} \mathrm{C}\right.$ dan $\left.65 \pm 5 \%\right)$ sebanyak $4-5$ siklus.

Vatandoost at al. (2004) di Iran yang juga meneliti resistensi nyamuk $C x$. quinquefasciatus lapangan dan laboratorium, menemukan nyamuk lapangan lebih resisten dibandingkan nyamuk laboratorium. Beberapa penelitian lain yang melaporkan resistensi nyamuk $C x$. quinquefasciatus adalah India, Venezuela, Goa, Thailand seperti disebutkan Vatandoost et al. (2004). Hasil ini bersesuaian dengan hasil Gionar (2005) (Indonesia) yang menyatakan bahwa nyamuk lapangan memperlihatkan gejala toleran terhadap 
insektisida organofosfat. Hal ini kemungkinan karena nyamuk lapangan merupakan keturunan dari nyamuk yang tetap bertahan hidup setelah mendapat pajanan insektisida baik yang dilakukan oleh masyarakat maupun dinas kesehatan dalam rangka program pengendalian nyamuk Ae. aegypti untuk mengurangi kejadian penyakit akibat vektor nyamuk. Vatandoost et al. (2004), menemukan bahwa pajanan insektisida sintetis menyebabkan nyamuk strain lapangan resisten terhadap DDT $4 \%$ dan bendiocarb $0,1 \%$ serta toleran terhadap malathion $5 \%$, permethrin $0,75 \%$, deltametrin $0,05 \%$, lambdacyhalothrin $0,05 \%$ dan etofenprox $5 \%$, sedangkan nyamuk strain laboratorium resisten terhadap DDT 4\% serta masih rentan terhadap semua insektisida lain yang digunakan. Othman et al. (2008), melaporkan di Malaysia, Ae. albopicus resisten terhadap permethrin. Di Thailand, Chareonviriyahpap et al. (1999) melaporkan Ae. aegypti resisten terhadap malathion, fenitrothion dan temephos.

Penelitian insektisida sintetis yang digunakan di negara berkembang (Indonesia, Malaysia, Iran, Brazil, Venezuela, Goa, India, Thailand) memperlihatkan adanya dampak nyata terhadap nyamuk, khususnya nyamuk lapangan, yaitu nyamuk tetap hidup (resisten) dan memiliki daya hidup yang lebih kuat dengan diantara buktinya angka fekunditas yang lebih banyak dan lama hidup yang lebih panjang dibandingkan dengan nyamuk kontrol. Terkait dengan program pemerintah Indonesia dalam pengendalian nyamuk menggunakan insektisida sintetis perlu dilakukan evaluasi terhadap program tersebut. Program pengendalian nyamuk menggunakan bahan kimia sintetis dimaksudkan untuk mengurangi nyamuk, tetapi jika pada kenyataannya yang terjadi justru sebaliknya, nyamuk tidak sepenuhnya dapat dikendalikan bahkan populasinya semakin bertambah dan lama hidup menjadi lebih panjang, maka tujuan program untuk menghilangkan gangguan nyamuk tersebut dapat dikatakan tidak berhasil, karena program ini dapat menyebabkan nyamuk lebih banyak dan selanjutnya nyamuk akan menambah gangguan.

Perlu dipertanyakan apakah insektisida sintesis masih efektif digunakan sebagai pengendali nyamuk. Dalam penelitian ini, insektisida nabati bunga keluwih jantan bakar dapat digunakan sebagai insektisida alternatif pengganti karena insektisida ini tidak merubah daya hidup dan tidak menyebabkan nyamuk resisten. Kandidat insektisida nabati ini banyak terdapat indigenous di Indonesia. Penelitian ini dapat digunakan sebagai inisiasi generalisasi bahwa bahan alami lebih aman digunakan sebagai pengendali nyamuk dibandingkan dengan bahan sintetis.

\section{KESIMPULAN}

Paparan $\mathrm{LC}_{50}$ insektisida sintetis berbahan aktif transflutrin dan d-allethrin pada nyamuk dewasa menguatkan nyamuk pada generasi filial 1 (anak), yaitu meningkatkan angka fekunditas, dan memperpanjang lama hidup nyamuk. Nyamuk yang tidak mati akibat pajanan insektisida sintetis berpotensi lebih kuat dan mampu berkembang biak lebih banyak. Bertambah lama hidup nyamuk akan meningkatkan kesempatan nyamuk untuk berbiak. Upaya mengendalikan nyamuk dengan insektisida sintetis memberi hasil sebaliknya, yaitu meningkatkan jumlah nyamuk. Paparan $\mathrm{LC}_{50}$ insektisida alami bunga keluwih jantan yang dibakar tidak menyebabkan perbedaan angka fekunditas pada Ae. aegypti sedangkan insektisida sintetis meningkatkan angka fekunditas. Penggunaan insektisida pertanian dan rumah tangga yang semakin banyak, akan semakin memperbanyak populasi nyamuk karena nyamuk yang tidak mati menjadi lebih kuat.

\section{UCAPAN TERIMA KASIH}

Terima kasih kami sampaikan kepada semua tim yang telah membantu selama penelitian ini berlangsung, mulai dari persiapan, pelaksanaan, hingga proses penulisan.

\section{DAFTAR PUSTAKA}

Antonio GE, Sánchez D, Williams T, Marina CF, 2009. Paradoxical effects of sublethal exposure to the naturally derived insecticide spinosad in the dengue vector mosquito, Aedes aegypti. Pest Management Science 65:323-326. doi: 10.1002/ ps.1683. doi: http://dx.doi.org/10.1002/ps.1683. 
[B2P2VRP]BalaiBesarPenelitiandanPengembangan Vektor dan Reservoar Penyakit. 2011. Uji kaji insektisida di laboratorium. Tersedia pada: http:// epitropcommunity.blogspot.com/2011/01/ujikaji-insektisida-di-laboratorium.html [diakses 6 January 2012].

Chareonviriyahpap T, Aum-Aung B, Ratanatham S. 1999. Current insecticide resistance patterns in mosquito vectors in Thailand. Southeast Asian Journal of Tropical Medicine and Public Health 30:184-194.

Davies TGE, Field LM, Usherwood PNR, Willianson MS. 2007. Clinical Review: DDT, pyrethrins, pyrethroids and insect sodium channels. IUBMB Life 59:151-162.

Davies TGE, O'Reilly AO, Field LM, Wallace BA, Williamson MS. 2008. Perspective: knockdown resistance to DDT and pyrethroids: from targetsite mutations to molecular modeling. Pest Management Science 64:1126-1130. doi: http:// dx.doi.org/10.1002/ps.1617.

De-Freitas RM, Codeço CT, De-Oliveira RL. 2007. Daily survival rates and dispersal of Aedes aegypti females in Rio De Janeiro, Brazil. The American Journal of Tropical Medicine and Hygiene 76:659-665.

Edwards CA. 2004. Pesticides, Pollution A to Z. Available from http://www.encyclopedia. com/ topic/ Pesticides. aspx [accessed 26 Des 2014].

Focks DA, Barrera R. 2007. Dengue transmission dynamics: assessment and implications for control, World Health Organization/Tropical Disease Research. Available at: http://www.tropika.net/svc/ review/061001-Dengue_Transmission_dynamics [accessed 6 January 2012].

Gionar YR, Zubaidah S, Stoops CA, Bangs MJ. 2005. Penggunaan metode microtitre plate assay untuk deteksi gejala kekebalan terhadap insektisida OP pada tiga spesies nyamuk di Indonesia. Di dalam: Prosiding Seminar Nasional Parasitologi dan Entomologi dalam Peringatan Hari Nyamuk $V$ (Bandung, 19 Agustus 2005). pp. 8-11. Bandung: Universitas Maranatha Bandung.

Kementerian Kesehatan RI. 2013. Kebijakan nasional pengendalian DBD Direktorat Pengendalian Penyakit Bersumber Binatang, Direktorat Jenderal PP \& PL Kementerian Kesehatan RI. Available at: http:/www.scribd.com/doc/760335 11/Kebijakan-Pengendalian-Demam-BerdarahDengue-Kalteng [accessed 6 January 2012].

Othman WN, Ahmad NW, Lim LH, Dhang CC, Mustapha WN, Hadi AA, Azirun MS. 2008. Detection of permethrin resistance in $\mathrm{Ae}$ albopictus Skuse, collected from Titiwangsa Zone, Kuala Lumpur Malaysia. Proc. of ASEAN
Congr. Trop Med and Parasitol, Parasites: a Hidden threat to Global Health 3:69-77.

Shinya H. 2010. Mukjizat mikroba, mengubah mikroba dalam tubuhkitamenjadimenguntungkan Di dalam: Anshor Z. (Ed.), The Microbes Factor (terjemahan). Jakarta: Gramedia Pustaka Utama.

Srisawat R, Komalamisra N, Apiwathnasorn C, Paeporn P, Roytrakul S, Rongsriyam Y, Eshita Y. 2012. Research Note. Field-collected permethrinresistant Aedes aegypti from Central Thailand contain point mutations in the domain IIS6 of the sodium channel gene (KDR). The Southeast Asian Journal of Tropical Medicine and Public Health 43:5690-10

Vasuki V. 1999. Influence of IGR treatment on oviposition of three species of vector mosquitos at sublethal concentrations. The Southeast Asian Journal of Tropical Medicine and Public Health 30:200-203.

Vatandoost H, Ezeddinloo L, Mahvi AH, Abai MR, Kia EB, Mobedi I. 2004. Enhanced tolerance of house mosquito to different insecticides due to agricultural and household pesticides in sewage system of Tehran, Iran. Iranian Journal of Environmental Health Science \& Engineering $1: 42-45$.

Wahyuningsih NE, Nurussakinah F, Siswoyowati. 2009. Aerosol propoxure insecticide impact towards Ae. aegypti and Ae. albopictus mosquito life times. In: Environmental health international seminar and workshop research paper writing and publication: Responding to global environmental health challenges, Bogor, Indonesia.

World Health Organization. CDS Prevention and Control. 1998. Report of the WHO informal consultation, test procedures for Insecticide resistance monitoring in malaria vectors, bioefficacy and persistene of insecticides on treated surfaces. Geneva: WHO.

World Health Organization. 2008. Pesticides, WHO Training Package for the Health Sector. Children's Health and the Environment. July 2008 version. Available at: www.who.int/ceh [accessed 28 December 2014].

World Health Organization. 2009. Guidelines for efficacy Testing of Household Insecticide Products: Mosquito Coils, Vaporizer Mats, Liquid Vaporizers, Ambient Emanators And Aerosols. Control of Neglected Tropical Diseases, WHO Pesticide Evaluation Scheme. Available at: http:// apps.who.int/iris/bitstream/10665/70071/1/ WHO_HTM_NTD_WHOPES_2009.3_eng.pdf. [accessed 28 December 2014]. 